\title{
Challenges of Women in Educational Leadership Position in Tano North Municipality of Ahafo Region, Ghana
}

\author{
Yaw Boakye Djan \\ St James Seminary and Senior High School, Abesim-Sunyani \\ Asante Gordon \\ Nkoranza Senior High/Technical School, Nkoranza-Bon East
}

\begin{abstract}
The study explored the challenges of women in educational leadership in Tano North Municipality, Ahafo Region of Ghana. This was a qualitative study which employed case study design. Purposive sampling technique was used to select participants comprising 15 women in educational leadership position for the study. Semi-structured interview guide were the instruments used for data collection. The data was analysed using thematic approach. It emerged that some teachers do not accord female heads the necessary respect due to their culture, religious background and perception about women in general. Also, the problem of heavy workload associated with their new positions posed challenges to women in educational leadership position. It was established that mentoring, professional development coupled with leadership and administrative support help women in leadership positions to excel. It is recommended that Tano North Municipal Education office and other gender-based groups should periodically organize leadership training programmes or seminars for women to prepare them professionally for leadership positions.
\end{abstract}

Keywords: Leadership, Subordinates, Gender, Equality, Position.

DOI: $10.7176 / \mathrm{JEP} / 11-31-04$

Publication date: November $30^{\text {th }} 2020$

\section{Introduction}

Worldwide, women are underprivileged in terms of leadership representation both in the public and private sectors of our national life. (Anigwe, 2013). Recently, the important role of women in educational development and the economy has stimulated the need for women involvement in the educational leadership position. Since the Beijing Conference in 1995, women have gained prominence in global thrifts and policies resulting in increased exposure to leadership positions. The conference in Beijing manifest a turning point in women empowerment and expedite action for women in leadership development or advancement.

It is generally acknowledged that national discourse and gender stereotypes in education in relation to planned positioning and governance qualities impart the capability of women to effectively seek public office. People's opinions and attitudes toward women affects their competence to engage themselves in public dialogue. Gender stereotypes often put females at the margin prior to decision - making process. In the view of Elson (2005) the challenges women continue to face in educational leadership position is based upon the sexual characteristics, patriarchy and division of labour in the society. Women's labour is not to a larger extent flexible. "It cannot widen to cover all the deficiencies left by reduced public operating expense. It cannot absorb all the shocks of adjustment" (Baah-Boateng, 2009 p.128)

Accordingly, women participation and progress in educational leadership and politics in Africa is still behind that of men (Nebolisa, 2009). Reasons accounting for the low participation of women in active decision-making process may be assigned to poverty, lack of resources, religious and cultural beliefs, societal norms and customs and ignorance (Baah-Boateng 2009). According to the 2010 Population and Housing Census, the gender structure of Ghana's population revealed that female constitutes about $51 \%$ of the population; Even though there has been some significant increase in participation in educational leadership positions in Ghana, their contribution in the socio- political and economic growth and development is still low (Elson, 2005).

Gender variation may affect the physical condition of women and girls, especially in developing countries with relatively low life expectancy, high illiteracy rate, famine, diseases and widespread poverty (Baah-Boateng, 2009). In some traditional societies in Ghana, educating girls is considered a misuse of family resources because girls may join their husband's family when they marry, and will not contribute to their family of orientation.

Some Ghanaian cultural practices and norms promotes gender inequalities in education depriving women and young children the opportunity to harness their talents, potentials and leadership skills. These cultural practices include female slave marriage (trokosi), widowhood rites, early marriage or force marriage, child labour practices, banishment of women alleged or suspected to be witches and female genital mutilation (FGM) (Ngaaso \& Atom, 2011). According to Ngaaso and Attom (2011, p.13) 'unfortunately, there are certain people who use culture to justify discriminatory practices against women and other social group'. According to Amoah (1986) as cited by Ngaaso and Attom (2011) in Ghana, a strong successful woman is regarded as a witch and thus marginalized and 
demonized in a similar way.

Equally, (Ngaaso \& Atom, 2011) stated that a number of laws have been enacted to prohibit some of these destructive gender-based practices. These laws include the Criminal Code Act, 1984, Act 554 outlaw religious oppression of girls and Act 484 against Female Genital Mutilation (FGM). Ghana is also a party to the Convention on the Elimination of all forms of Discrimination against Women (CEDAW). Article 26 (2) of the 1992 Constitution of the republic of Ghana prohibits customary practices which dehumanized or are harmful to the physical and mental well-being of all persons. The African Charter on Human and People's Rights and its women's Protocol have requirements outlawing cultural practices which discriminate against any person, including women. Ghana's pledge under International Human Rights Instrument includes the support of cultural norms which give confidence to the rights and progress of women and the elimination of practices which discriminate against them. However, social pressure from society and the family make it complex to assess the impact of the laws passed against these cultural practices. Lack of prompt and sufficient responses from law enforcement agencies such as the police, the law court and Commission on Human Rights and Administrative Justice (CHRAJ) discourage women from reporting cases of maltreatment.

Education is very essential to the accelerated pace of social, political and economic development of every country. This is the rationale for apportioning substantial size of nations' Gross Domestic Product (GDP) to expand the educational sector. Ghana sets aside, between 7.6 billion cedis and 9.9 billion cedis of the annual development and recurrent expenditure to education (MOF, 2018). This includes payment for human resources, like the education administrators, and provision of educational infrastructure to increase accessibility.

Ghana is in the centre of the nation's encouraging for gender equality and women empowerment prosecution in the educational sector. Women have been encouraged through reasonable processes to positions of accountability at all stages. This pledge has been cherished in the 1992 Constitution, and other government intermediate strategies and programmes, which obviously lay down the concerns of gender equality and women's political, social and economic empowerment in national development. Modifications in the educational sector have ensured proficient delivery at all levels. The focus is more on educational output and institutions are given greater dominion in achieving the national goals which focus on effectiveness (GOG, 2010).

Discrepancies in gender equality are addressed by all actors in the world at all levels. The ministry of education has been in the forefront in ensuring gender equity in the organizational positions in the country. Men and women administrators are given the same opportunities to work and be useful in the delivery of services in the country. However, there are still prejudices in various parts of the nation towards female administrators, which have outlawed effective delivery of services. In Ghana, although there are many women in the teaching career, the number that holds leadership positions has been low. There are a number of challenges facing women in educational leadership compared to their male counterparts. There has been little focus on the challenges facing women in educational leadership in the Municipality and the reasons why some of them perform below expectation.

There are relatively fewer women managers and administrators in the Municipality compared to other parts of the country. There are socio-cultural and managerial issues that are discriminating against women that necessitate investigation and amicable solution so that they can be addressed harmoniously. Despite these, it should be noted that there are opportunities that women in educational leadership can seize to enhance output of work, which include learning of Information Communication and Technology (ICT), doing away with destructive cultural practices and taking up opportunities to upgrade themselves.

The study also sought to find out from women in educational leadership positions how they deal with the challenges they faced in discharge of their duties in their institutions. The responses from the female head teachers are discussed under sub-theme that emerged from the data.

\section{Challenges facing women in educational leadership position}

Kiruriti (2010) opines that women in educational leadership in most cases find themselves not fully being established by the society they work with, making them feel their support to the society not imperative. At this contemporary age, there are people who still believe that women are not suitably expert to contest successfully with men for advanced job status in educational sector. Thus, such structure of beliefs devalues women liberation efforts. Women therefore have had obscure time convincing men in some communities that they are competent of leading. In most cases they have to work extra hard in their profession to be identified and established as compared to their male counterparts who are gladly accepted in the community.

Emory (2008) observed that, many women lose their drive to excel due to the many obstacles met along the path of becoming a manager or leader. Moreover, men and women are generally not prepared to work under a woman because they feel that the moment a woman becomes a manager she has lost all her femininity (Commbs, 2004). Women managers are always at fault if they are strong they are regarded as aggressive, tough not feminine, if they are jovial they are permissive, if they cry they are emotional, if they make a mistake, remarks like" That you can expect from a woman "are heard all over which irritating and discriminating means (Commbs, 2004).

According to Emory (2008), obstacles that women face in discharge of their duties include discrimination, 
stereotyping, prejudice, family demands and lack of opportunities. Ruth (1987) also observed that, a married woman who works outside the home actually carries two jobs. There is evidence to show that most of the household labour is done by an adult woman (Baxter, 2002). In the execution of managerial duties, both male and female head teachers are saddle with similar challenges in the management of secondary schools (Nzeli, 2013). However, female principals are often faced with societal demands and traditions that males do not face. The women principals are expected to complete their family responsibilities, maternal as well as managing the schools (Celikten \& Yeni, 2004). In the African context, traditional beliefs and cultural attitudes regarding the role and status of women in society are still prevalent and many women are part of this system finding it difficult to dislocate from this culture and tradition.

These challenges compound the problem of female prejudices as captured by the data from research question 3 , and thus makes it difficult for female leadership. Hence, it may be argued that given a level playground, female heads may perform equally well as their male counterparts if not better. The fact that women tend to face more obstacles on their way up the ladder has been established by Ruderman and Ohlott (2002). Their research shows the unique challenges women face as they develop as managers and leaders. After conducting 61 interviews and collecting 276 surveys, they discovered 5 themes characterizing the challenges facing female managers, but which are vital for female developmental needs. These are: authenticity, wholeness, self-clarity, connection and agency. Among the many career barriers women encounter at all levels are prejudice, resistance to women's leadership, leadership style issues and family demands. For organisations that are keen to develop female leaders, these obstacles must be addressed (Eagly \& Carli (2007)). Success in the workplace as women in terms of balancing work and family may come at a high cost in the form of stress (Easton, 2007). This stress, if not handled carefully, could have dire effects on their careers and even their roles and obligations to their families. This study suggests there are widespread effects of the discriminatory behaviour against women that may be derogatory to an organization's effectiveness and performance.

Cultural and religious issues become more evident especially when a female head works in different cultural set up (Johannes, 2010). Women in educational leadership positions in town and countryside areas are hard hit by prejudices because most men in such areas are the custodians of customs (Johannes, 2010). Female heads in the educational sector are scrutinized for their social behaviour more than men in some communities, making their work difficult. Female heads of some secondary schools and in District Educational Directorate (DED) have challenges when dealing with adolescence behavioral problems, mainly when there are discipline cases concerning boy-girl relationship and drug abuse (Kiruriti, 2010). Students, particularly boys prejudice women decisions and feel the heads of educational institutions are invading their secretive affairs, making disciplinary measures complicated in such condition. This can cause unrest in the school such as demonstrations, burning and destroying school properties.

Eagly and Carli (2007) wrote that studies on gender and leadership reveal the concerns about interaction between leader uniqueness and gendered stereotypes. Society frequently relates leader characteristics to stereotypical male traits such as ambition, confidence, dominance, and boldness. Female stereotypical traits, however, such as kindness, helpfulness, warmth, and gentleness do not make women effective leaders. However, Keohane (2007) explains that this statement is deceptive because successful leaders ought to be able to opt for the most suitable characteristics depending on the settings, problems being solved and audience.

According to Kiruriti (2010) in many cases the female head in educational institutions is alleged to be inept of instilling discipline in the school. This also gives female administrators in school's hard time when reporting the same to male superiors. Women have not been trained in capacity building. Women head teachers are not empowered throughout competence construction to take up administrative responsibilities. Lack of capacity building among women head teachers is seen as a major contributor to lack of appointment to administrative positions. Due to lack of proper capacity building, few females are appointed to educational leadership positions.

Acquah (2001) explained in a study he conducted on school attendance in some selected schools in Ashanti Region where most of the schools he visited had classes without teachers. In some schools, teachers are late up to about 30 minutes, especially for the first period and after break, teachers do not arrive in their classes when they are expected to. The responses gathered indicate that teachers' time of arrival to class had serious effects on headteachers. This confirms the circumstance explained by The World Bank Report (2008) that teachers living long distances from school's experience transportation difficulties; they have to track long distances to school and those, especially in rural areas, engage in farming activities; and all these confront the instructional time use. In spite of the distances teachers ply before they get to school, it cannot be used as an excuse for affecting learning.

World Bank (2008) which revealed that teacher-absenteeism is an issue of great concern in basic schools, especially in sub-Saharan Africa and ranges from $11 \%$ in Peru to $27 \%$ in Uganda. Teachers' attendance or regularity in school also inhibits the use of instructional time, especially in terms of both students' access to education and the nature of that access. A widespread problem of teacher-absenteeism is likely to contribute to poor student performance. The prevailing evidence is that teacher-absenteeism at basic school level in Ghana appears to have worsened in the last 15 years (World Bank Report, 2008). The World Bank Impact Evaluation of 
Basic Education (2003) found that, in Ghana, nearly 13\% of teachers have been absent in the past months compared to just over $4 \%$ in (1988). It was also observed that in (1988), 85\% of schools did not suffer at all; whereas this figure has now fallen to $61 \%$, with $13 \%$ of schools with over one-third of the teachers being absent for reasons other than sickness in the past months (World Bank, 2008). The study also found absenteeism to be significantly worse in rural schools than in urban schools, and worse in public schools compared to private schools.

\section{Overcoming the challenges facing women in educational leadership position}

Holt (1981) advocates that mentors, both male and female, may be the top most important factor in a manager's professional progress. Mentor can advocate policies and programs for career development, open doors, initiate contact and make recommendations. Notwithstanding the importance of mentoring, research showed that there appears to be a lack of accessible male or female mentors for women. When males do act as mentors, they tend to sponsor male, or someone who is most like them (Gardener, 2011).

One reason why mentoring may not be willingly available to women may be that women don't "fit" into the comfort zone of male mentors (Galton, 2009). Another reason may be that women are still the unknown quantity and are not perceived by some men as loyal or trustworthy and, therefore, may be seen as a great risk factor for the mentor. Fleming points out another problem of men choosing women as protégés is the sexual connotation that is attached to this relationship or the threat of actual sexual harassment in the form of sexual bribery. Michael (2008) found out that one of the critical needs of female head teachers is to create a work environment where they can reach out for support from superiors at all times.

This assertion by women in educational leadership position are in support of Warring (2009) who suggests that mentors both male and female, may be the single most important factor in an administrator's career development. Mentors can suggest strategies for career mobility, open doors, initiate contact and make recommendations Studies have confirmed the criticality of social relationships and mentorship in women's career advancement (Roe, 2013; Spencer, 2013). This is because women tend to generally advance through a combination of critical social relationships and particular performance strategies (Ezzedeen \& Ritchey, 2009). Mentors are of importance because they offer two general types of behaviours or functions: career development functions, which is believed to facilitate the protégé's advancement in the organization, and psychosocial functions, which is believed to contribute to the protégé's personal growth and professional development (Roe, 2012). They are associated with providing positive outcomes for protégés such as promotions; higher incomes; mobility and career satisfaction than non-protégés. Women in leadership positions should institute mentorship scheme or program for school girls and a debriefing programme on male dominance for school boys. Such programmes will propel women to attain leadership positions and at the same time change male attitudes towards female leadership over time.

In addition, research does indicate that male teachers may benefit more from an informal level of 'mentoring' than their female equivalents. Clearly, mentoring when it does happen is one way to break down the barriers that women face, but it is not such a simple matter. Another way of overcoming barriers that is suggested in the literature is through networking. Networks provide a widening circle of personal and professional references that can assist in the promotion of women as candidates for positions. Networks can provide information through newsletters or word of mouth on systems that have job openings and contacts, offer advice on benefits of positions, salary, history and background of school boards (Roe, 2012). Women need to actively seek out networks with men and other women to gain visibility, information, advice and receive moral support as they pursue their careers (Rees). Various American networks such as Sex Equity in Educational Leadership (SEEL) and Women in School Administration (WISA) have been established. In Canada, the Federation of Women Teachers' Association (FWTA) provides different types of networking opportunities ranging from courses to prepare for the different leadership positions, to conferences, resource booklets, and a regular newsletter.

Additionally, The Canadian Teachers' Federation organizes an annual Status of Women conference. As Arhin (2012) stated in their study of women's support organizations, women need time to grow together professionally and to learn from other women. Arhin suggested that there is something special and celebratory for same sex members of all races and ethnic groups to come together. Perhaps one of the most compelling and powerful experiences that women have in the conferences and workshops for women is the camaraderie, the shared unspoken assumptions, and the revelation of one's experience which is understood (Arhin, 2012).

Gaining academic credentials is another way for women to overcome barriers to moving up the administrative ladder. Evidence suggests that women are attending graduate school in record numbers. Preparing for the role of principal, especially in higher institution, has been identified as a key in breaking down the barriers facing women. Hopefully, the trend of increased enrollment in graduate programs by women will begin to have an effect on the serious underrepresentation of women in leadership. It is important to remember, however, that to date the results have not been that encouraging (Warring, 2009).

A more formal way to decrease the barriers facing women seeking advancement in educational administration is through employment equity programs or affirmative action initiatives. Employment equity programs involve the systematic monitoring of who holds what jobs so that areas of concern, such as fair and representative work 
force and equality of treatment and outcome, become public (Walby, 2006). It is important to note that although hiring can be mandated by institutions, acceptance cannot. Promoting gender equity in the classroom is another way to help remove barriers for women. Girls are under-represented in compensatory educational programs and extracurricular programs. They are misrepresented and under-represented in co-curricular activities such as school club head, texts, department head, unit-leader, vice-principal and school Principal (Walby, 2006). Moreover, educators must be cognizant of the "hidden curriculum" and the devastating effects that gender inequality in school can have on girls. Spencer (2013) outline various steps to a bias-free classroom. Some of them include: set and enforce rules so boys do not monopolize attention and dominate all co-curricular activities.

Referring to Maslow's hierarchy of human needs, interpersonal relationships could be seen as resulting from the need for belongingness (Garudzo-Kusereka, 2009). Environmental factors are thus, regarded as important determinant of job satisfaction (Khan, Nawaz, Aleem \& Hamed, 2012:2699). According to Ellickson and Logsdon (2001) employee job satisfaction can be greatly affected by the social environment of the organization, especially, relationship with co-workers because cooperative co-workers are modest source of job satisfaction to each employee. It has also been proven that a good and supportive co-workers and interpersonal relationship in general, makes the job easier and enjoyable. This in turn increases job satisfaction levels of workers (Saif, Nawaz \& Jan, 2012).

Naval and Srivastava (2004) maintain that open communication, task independence, feeling of belongingness and coordination among employees increase the degree of job satisfaction (Saif, Nawaz \& Jan, 2012) and according to Hiroyuki, Kato and Ohashi (2007) and Karimi (2007) studies have shown that relation with colleagues or co-workers is the largest predictor of academicians' intention to leave an organization or not (Saif, Nawaz \& Jan, 2012). Chughtai and Zafar (2006) add by asserting that satisfaction with co-workers is an indicator of how highly university academicians value the nature of working relationship with co-workers (Saif, Nawaz \& Jan, 2012).

Shann (2001) in a study, relationship with pupils was highly ranked among other factors as making teachers satisfied with their job (Ngimbudzi, 2009). For Wood (2008) employees derive their job satisfaction from supportive administration because an informative and consultative administration makes employees comfortable with their jobs (Ngimbudzi, 2009:41). Woods and Weasmer (2002) also agree that collegial relationship ensures workers' job satisfaction, and that it is significant for teachers to have time to share experiences (Ngimbudzi, 2009).

Spencer (2013) assertion in their study on women's support in administrations they noted that women need time to grow together professionally and to learn from other women. Schmuck as cited by Spencer (2013) suggested that there is something special and celebratory for same sex members of all races and ethnic groups to come together. Besides, Dundas (2008) argued that work-life balance is the effective management and juggling act between paid work and all other activities that are essential to people such as family, community activities, voluntary work, personal development and leisure and recreation. Similarly, Greenhaus, Collins and Shaw (2003) posit that work-life balance is the extent to which an individual is equally engaged in-and equally satisfied with his or her work role and family role. Broers (2005) noted that it is very challenging to balance a successful career with a personal or family life. This can have an impact on an employee's satisfaction in his or her work and personal life's roles.

Virick, Lily and Casper (2007) therefore contend that employees who experience high work-life balance are those who exhibit similar investment of time and commitment to work and non-work domains. According to Hughes and Bozionelos (2007) work-life balance, which refers to individuals determining the balance between their work and non-work responsibilities, activities and aspirations is deemed a major factor in determining employee job satisfaction, and that family obligations are not the only issues that bring about challenges in worklife balance, but it includes activities such as hobbies which are outside work obligations. Throughout the world, workers, including teachers, perceive the ability to balance between workplace's needs and personal life's needs as an important issue (Mohd Noor, Stanton \& Young, 2009). Scholaris and Marks (2004) see work-life balance has important consequences for employee attitudes towards their organisations as well as for the lives of employees, and for Guest (2002) it is possible to investigate the trend of work-life balance and its developments which influence the well-being and job outcomes of employees at work. According to Deery (2008) much attention has been given to the issues that relate to maintaining and obtaining a work-life balance, but researchers such as Doherty and Manfredi (2006), Mohd Noor and Amat (2010), and Mohd Noor, Stanton and Young (2009) comment that less attention, has however, been given to finding the reality of work-life balance satisfaction in higher educational institutions. A lot of researches have been conducted to determine the association between work-life balance and attitudinal job outcomes such as job satisfaction and organisational commitment (Doherty \& Manfredi, 2006; Virick, Lily \& Casper, 2007; Youngcourt, 2005; Zin, 2006). Virick, Lily and Casper (2007) study on layoff survivors in a high tech company found that work-life balance is positively related to job satisfaction. Howard, Donofrio and Boles (2004) in a study also concluded that work-family conflict which reflects work-life balance issue is significantly related to satisfaction with job. 


\section{Methodology}

The study utilized case study with women in educational leadership as the population. Fifteen (15) participants comprising women in educational leadership position in the Municipality were selected for the study. This research made use of the purposive sampling method. According to Tanor (2011) the most important theory underlying the use of the purposive sampling is sampling with a purpose. Merriam (2002) argued that it is imperative to choose individuals from which one can discover a great deal about the issues essential to the purpose of the study, thus the term purposeful sampling. Therefore, to understand the challenges faced by women in educational leadership in the Tano North Municipality, individuals who were able to provide worthy information on the topic were selected. The most important aim was to get participants who were accessible, and willing to provide key information. Semi-structured interview guide was used for the data collection. Interviews were conducted at the respondents' own convenience. The initial interview questions were associated with the research questions of this study. Each interview lasted for about one hour and depended upon the participant's response. Field notes were taken on key points during the interviews. The field notes helped to track of the questions asked and where to go next in the interview. Issues that required follow up or further probing was also noted.

\subsection{Result and Discussion}

For the purpose of analysis, the following were used to represent the various categories of the participants. HTHead teachers (women in leadership position).

\section{Opposition from subordinates}

The results indicated that head teachers were confronted with the problem of opposition from teachers. It was commented by a HT-7:

Rebellious teachers on my staff normally create problems for me. The moment I suggest
something they rebel against my decision. It is hard to deal with these bad nuts because
they always do things negatively that affect my good intentions of helping the school to
progress. Due to this situations, some laudable plans have to be abandoned because
there is much opposition from teachers. I don't know if because I am a woman? [Field
interview data, 2019].

The findings were clear that opposition from teachers affected the work of female head teachers and this was in line with a study by Manu (2012) who found that both male and female head teachers faced opposition from their subordinates, however, female head teachers were more likely to be opposed by their subordinates as compared to their male counterparts.

\section{Deviant nature of teachers}

Deviant nature of some teachers was reported as one of the challenge confronting women in educational leadership positions. All the female superiors agreed that they were facing these challenges in their institutions. In line with this, one of them said:

"I realized after my third year in this school that there were some two teachers who were inciting others against me in the school. They did that to the former head teacher. I realized that if I do not act fast, those teachers are likely to give me the same problem. So I just moved to the office to report them and they were transferred". [Field interview data, 2019].

Another head teacher indicated:

“... Few teachers do not accord me the necessary respect. I am talking about two Muslins teachers. You know with our Muslim brothers they don't respect women. When I assumed office as the head of the school, they were not obeying what I was trying to bring on board. After talking to them, they have changed" [Field interview data, 2019]

She further explained:

"I think it is because of their culture or their religion. They do not respect women and so they brought it to work place. But I made them to understand that our work is different from their religion so they should not bring what they practice there to their work place". [Field interview data, 2019].

Another head teacher also explained that:

"When I came to this school, I noticed that teachers were not coming to school early. They would wait for you to tell them what to do before they do it. When some of them come to school, they can sit under the trees and be making calls throughout without going to classroom to teach when it is time. There was a particular teacher, who was not coming to school early. When comes she would be making calls throughout. At times, she would even leave the school before we close. I saw it to be a problem because 
that is not how a professional teacher should behave. You have to come to school on time and help the students to clean the compound and classrooms. As teachers, instructional period should be utilized well but teachers in this school were not teaching as expected. I saw that to be a problem. I talked to them and with time they have changed for the better". [Field interview data, 2019].

The data reveals that female school heads face difficulties in gaining acceptance and support from their subordinates. Most of them indicated that female school heads face difficulties in gaining acceptance and support from other administrators. One respondent in the interview indicated:

"I encounter some problems in dealing with my subordinates. The men who work under me feel I'm a woman. At times they don't take my instructions. The day that I will complain about their attitudes towards work, it will be worse the next day" (HT-3).

"...some of my teacher at times disobey my instructions which poses difficulty for the smooth running of the school administration" [HT-6]

The interview data indicated further that some male subordinates do not cooperate with the female head teachers. This could prevent them from functioning effectively. The views expressed above are a clear indication that some female school heads do not get the needed support from their subordinates and other school administrators. The findings is consistent with Emory's (2008) who observed that, many women lose their drive to excel due to obstacles along. Moreover, both men and women are generally not prepared to work under a woman because they feel that the moment a woman becomes a manager she has lost all her femininity (Commbs, 2004). Women managers are always regarded as aggressive, tough not feminine, if they are jovial they are permissive, if they cry they are emotional.

\section{Heavy workload}

Some of the head teachers indicated that the problem they faced were as a result of the heavy workload associated with their new positions as head. They said that the workload to some extent was too much and examples were given as, filling of documents, compiling teachers' profiles etc. They indicated that the work involved were not easy at all and although the school close at 3:00 pm because of the workload, they could still be in school up to 5:00 pm

The following are some of the views expressed by the head teachers:

"... as a married woman I have to go home on time and attend to my family. But the work load does not permit me to do so and this can affect my marital home”. [Field interview data, 2019].

“... at times I come to school at 7:00 am and close at 5: pm. As you can see I am even filling a form about the students' enrolment. [Field interview data, 2019].

“...The work that we do is very demanding. It becomes more challenging when your teachers are not supportive. Have you seen the pile of lesson notes book in front of me? I am going to inspect them and make the necessary corrections. [Field interview data, 2019].

The study showed that the lack of family support and interference from domestic responsibilities is another key challenge to female heads. This is reflected in statements like:

"I don't have enough time to perform duties as a homemaker. As a woman at childbearing stage, I am concerned about catering for my children needs. Most husbands do not compromise when it comes to the performance of roles such as cooking, cleaning the house and caring for the children" [Field interview data, 2019. HT-7].

The data is consistent with Emory's (2008) observation that, many women lose their drive to excel due to the many obstacles met along the path of becoming a leader. According to Emory (2008), these obstacles include family demands and lack of opportunities. Ruth (1987) also observed that, a married woman who works outside the home actually carries two jobs. There is evidence to show that most of the household labour is done by an adult woman (Baxter, 2002). In the execution of managerial duties, both male and female head teachers are saddle with similar challenges in the management of secondary schools (Nzeli, 2013). However, female leaders are often faced with societal demands and traditions including family responsibilities, maternal as well as managing the schools (Celikten \& Yeni, 2004).

These challenges increased the problem of female prejudices as captured by the data from research question 3 , and thus makes it difficult for female leadership. Hence, it may be argued that given the equal opportunity female heads may perform equally well or better compare to their male counterparts. The challenges faced by women in career progression is still established by Ruderman and Ohlott (2002). After conducting 61 interviews and collecting 276 surveys, they discovered 5 themes characterizing the challenges face by female managers, but 
which are vital for female developmental needs. These are: authenticity, wholeness, self-clarity, connection and agency. Among the many career barriers women encounter are prejudice, resistance to women's leadership, leadership style issues and family demands these obstacles women face must be addressed (Eagly \& Carli (2007)). Success in the workplace as women in terms of balancing work and family may come at a high cost in the form of stress (Easton, 2007). This study suggests there are widespread effects of the discriminatory behaviour against women that may be derogatory to an organization's effectiveness and performance

\section{Interpersonal Relationship}

It was cited by participants that in dealing with some of the challenges they encountered in their schools, female head teachers mentioned that building strong interpersonal relationship with subordinates as well as creating a working environment that foster friendly/interpersonal relationship among the subordinates themselves were the strategies they have been using to deal with problems they faced. It was shared by HT-3 thus:

When there are good interpersonal relationships among teachers and the head I believe most of the difficulties we (female head teachers) encounter will be reduced to the barest minimum. The issue is that the head must come to the level of her subordinates while her subordinates must also accord their head the maximum respect and needed cooperation [Field interview data, 2019].

Referring to Maslow's hierarchy of human needs, interpersonal relationships could be seen as resulting from the need for belongingness (Garudzo-Kusereka, 2009). Environmental factors are thus, regarded as important determinant of job satisfaction (Khan, Nawaz, Aleem \& Hamed, 2012). According to Ellickson and Logsdon (2001) employee job satisfaction can be greatly affected by the social environment of the organization, especially, relationship with co-workers because cooperative co-workers are modest source of job satisfaction to each employee. It has also been proven that a good and supportive co-workers and interpersonal relationship in general, makes the job easier and enjoyable. This in turn increases job satisfaction levels of workers (Saif, Nawaz \& Jan, 2012).

Naval and Srivastava (2004) maintain that open communication, task independence, feeling of belongingness and coordination among employees increase the degree of job satisfaction (Saif, Nawaz \& Jan, 2012) and according to Karimi (2007) studies have shown that relation with colleagues or co-workers is the largest predictor of academicians' intention to leave an organization or not (Saif, Nawaz \& Jan, 2012). For Wood (2008) employees derive their job satisfaction from supportive administration because an informative and consultative administration makes employees comfortable with their jobs (Ngimbudzi, 2009:41). Woods and Weasmer (2002) also agree that collegial relationship ensures workers' job satisfaction, and that it is significant for teachers to have time to share experiences (Ngimbudzi, 2009:41).

\section{Professional development}

Professional development was one of the themes that was studied. Women in educational leadership position explained that the district education directorate in collaboration with some Non-governmental organizations in the district frequently organizes workshop on conflict resolution and management. They skills acquired at the workshop have helped them to deal with challenges in the schools. This view by women in educational leadership position in Tano North Municipality is in line with Irby and Brown (1998) assertion in their study on women's support in administrations they noted that women need time to grow together professionally and to learn from other women.

The following are some excerpts from the participants:

$$
\begin{aligned}
& \text { "... Workshops on conflict management and resolution are at times } \\
& \text { organized for head teachers in this district. I have acquired some skills which } \\
& \text { helped me to tackle problems in my school." [HT-7] } \\
& \text { Am very thankful to my district director for organizing workshops on how to } \\
& \text { deal with conflict situations in our schools [HT-2] }
\end{aligned}
$$

The views expressed give credence to the fact that the Ghana Education Service and gender-based organizations should periodically organize leadership training programmes for women to prepare them professionally for leadership positions.

\section{Work-life Balance}

It was noted by the head teachers during the interviews that an important strategy that could be used by female heads in solving the challenges they encounter is by employing work-life balance strategies. HT-5 commented that:

"Am a mother and a wife, a situation I have been managing for many years. I have to structure my daily routines such that I can perform both roles effectively" [Field interview data, 2019]. 
This concurs with Dundas (2008) views that work-life balance is the effective management and juggling act between paid work and all other activities that are essential to people such as family, community activities, voluntary work, personal development, leisure and recreation. Similarly, Greenhaus, Collins and Shaw (2003) posit that work-life balance is the extent to which an individual is equally engaged in-and equally satisfied with his or her work role and family role. Broers (2005) noted that it is very challenging to balance a successful career with a personal or family life. This can have an impact on an employee's satisfaction in his or her work and personal life's roles.

In relation to work-life balance HT-13 commented:

"I have a time schedule for when to end performance of administrative duties and when to take care of home and other activities. Besides I take time to enjoy quality rest for myself and this strategy has gone a long way to help me as a female head teacher"

Similarly, HT-10 stressed: [Field interview data, 2019].

". I have to practise effective time management in my work balance in order to achieve good results." [Field interview data, 2019]

Virick, Lily and Casper (2007) contend that employees who experience high work-life balance are those who exhibit similar investment of time and commitment to work and non-work domains. According to Hughes and Bozionelos (2007) work-life balance, which refers to individuals determining the balance between their work and non-work responsibilities, activities and aspirations is deemed a major factor in determining employee job satisfaction, and that family obligations are not the only issues that bring about challenges in work-life balance, but it includes activities such as hobbies which are outside work obligations.

A lot of researches have been conducted to determine the association between work-life balance and attitudinal job outcomes such as job satisfaction and organisational commitment (Doherty \& Manfredi, 2006; Virick, Lily \& Casper, 2007; Youngcourt, 2005). Virick, Lily and Casper's (2007) study on layoff survivors in a high tech company found that work-life balance is positively related to job satisfaction. Howard, Donofrio and Boles (2004) in a study also concluded that work-family conflict which reflects work-life balance issue is significantly related to satisfaction with job.

\section{Leadership and Administrative Support}

The female head teachers reported that seeking administrative support from superiors was one sure way that could be beneficial to female head teachers. Hence, another sub-theme emerged from the finding was seeking administrative support. Some of the women in educational leadership indicated that they rely on superiors and mentors for guidance to enable them deal with solve challenges that confront them. Sharing her experience HT-5 had this to say:

"I have a mentors who have deep knowledge in educational administration and educational leadership who I consult in critical times." [Field interview data, 2019]

This implies that some female head teachers rely on their superiors for support in dealing with their challenges. This result supports Michael (2008) who found that one of the critical needs of female head teachers is to create a work environment where they can reach out for support from superiors at all times.

This assertion by women in educational leadership position are in support of Holt (1981) who suggests that mentors both male and female, may be the single most important factor in an administrator's career development. Mentors can suggest strategies for career mobility, open doors, initiate contact and make recommendations. The following are some of the excerpts from the participants:

$$
\begin{aligned}
& \text { ".... for a leader to be successful you need someone who will serve as a } \\
& \text { mentor to you. My mentor has been guiding me when I am confronted with } \\
& \text { challenges". [HT-7]5 } \\
& \text { ".. I thank God that I have someone at the District Education Office who is } \\
& \text { my mentor. This woman is like a mother to me. Sometime ago, I had a } \\
& \text { problem with one of m5y teachers which nearly resulted into fight. But when } \\
& \text { I discussed the issue with her she counsels me and the problem was resolved" } \\
& \text { [HT-4] } \\
& \text { "...I have people whom I confine in when the going is getting tough. I mean } \\
& \text { when I' m having challenges. They have been very helpful. They help me to } \\
& \text { deal with problems in my school". [HT-1] }
\end{aligned}
$$

Studies have confirmed the criticality of social relationships and mentorship in women's career advancement (Burke \& McKeen, 1990; Combs, 2003; Ibarra, 1993; Wentling, 2003). This is beca5use women tend to generally advance through a combination of critical social relationships and particular performance strategies (Ezzedeen \& Ritchey, 2009). Mentors are of importance because they offer two general types of behaviours or functions: career development functions, which is believed to facilitate the protégé's advancement in the organization, and 
psychosocial functions, which is believed to contribute to the protégé's personal growth and professional development (Ragins \& Cotton, 1999). They are associated with providing positive outcomes. Women in leadership positions should institute mentorship scheme or program for school girls and a debriefing programme on male dominance for school boys. Such programmes will propel women to attain leadership positions and at the same time change male attitudes towards female leadership over time.

\section{Conclusions}

This study concludes that some teachers do not accord female heads the necessary cooperation because of their gender; this creates challenges for female heads. Some teachers do not accord women in educational leadership the necessary respect due to their cultural orientation, religious background and perceptions. Also, the problem of heavy workload associated with leadership positions pose challenges to women in educational leadership. Premised on the findings of the study, it is concluded that mentoring, professional development coupled with social support helped women in leadership positions to excel.

\section{Acknowledgement}

My acknowledgement will fall short of expectation without saluting the following people, my beautiful wife, Josephine Twenewaa, my two lovely daughters, Nana Afia Boakye-Djan and Ohemaa Adubea Boakye-Djan, my dear mother Comfort Adubea and all my siblings. Dr. Obeng Kwasi Camara, a Senior Lecturer at the University of Cape Coast, Economics Department, Dr. Stephen Yeboah, a senior Research Scientist at the Centre for Scientific and Industrial Research (Crop Research Institute) and Frederick Ameyaw a lecturer at Bagabaga College of Education, Tamale. Finally, I am indebted to all the teaching staff, especially female head of schools in the Tano North Municipality where the data was collected for the study.

\section{References}

Anigwe, J. (2013). Women in political positions in Nigeria. Ibadan: Houseman Publications.

Arhin, D. (2012). The success of private basic schools in Ghana: The case of three schools in

Acquah, A. (2001). Understanding state-organized education in Ghana. Accra: Black Mask.

Amoah, E. (1986). Women, witches and social change in Ghana. Accra. Adinkra Press.

Baah-Boateng, W. (2009). Gender perspective of labour market discrimination in Ghana: An Unpublished PhD Thesis, Department of Economics, University of Ghana. Accra: Ghana.

Banda, F. (2005). Women, law, and human rights: An African perspective. Oxford-Portland Oregon: Hart Publishing

Baxter, D. D. (2002). School context, student attitudes and behaviour, and academic achievement: an exploratory analysis. London: Sage Publications.

Broers, C. M. (2005). Career and family: The role of social support. (Published PhD Thesis), Oxford University. United Kingdom.

Celikten, S., \& Yeni, W. (2004). Guidelines for managing motivation. Business Horizons, 23, 61-6.

Chin, J. L. (2007). Comment: Diversity and leadership. American Psychologist, 62(6), 608-609.

Chughtai, A. A., \& Zafar, S. (2006). Antecedents and consequences of organizational commitment among Pakistani university teachers. Applied Human Resource Research, 11(1), 39-64.

Combs, R. (2003). Masculinity, Law and the Family. London: Routledge.

Deery, S. (2008). The double-bind dilemma for women in leadership: Damned if you do, doomed if you don't. Retrieved June 10, 2019, from http://www.catalyst.org/files/full/2007\%20Double\%20Bind.pdf

Eagly, A. H., \& Carli, L. L. (2007). Through the labyrinth: The truth about how women become leaders. Boston, MA: Harvard Business School Press.

Easton, A. (2007). Successful women of the Americas: The same or different? Management Research News, 29(9), $552-572$

Ellickson, K., \& Logsdon, C. (2001). Goal setting and monetary incentives: Motivational tools that can work too well. Compensation and Benefits Review, 26(3), 41-46.

Elson, W. (2005). Women in economic development. London: Sage Publication.

Ely, R. J., Ibarra, H., \& Kolb, D. (2011). Taking gender into account: Theory and design for women's leadership development programs. Insead - Working Paper, 10(3).

Emory, W. (2008). Leadership: Qualities that distinguish women [Electronic version]. Financial Executive, 21(6), $32-36$

Ezzedeen, G. T., \& Ritchey, E. (2009). Women and the labyrinth of leadership. Harvard Business Review, 4, $63-$ 71.

Galton L. (2009) Education, wage rates and the division of labour between husband and wife. Journal of Marriage and the Family, 38(74), 473-84.

Gardner, D. G. (2011). Role of transformational and transactional leadership on job satisfaction and career 
satisfaction. Business and Economic Horizons, 1(1), 29-38.

Garudzo-Kusereka, L. (2009). Factors influencing the motivation of Zimbabwean secondary School. Harare: Madson Publications.

Government of Ghana [GOG] (2010). Growth and poverty reduction strategy, 2006-2009. Accra; Policy Framework.

Greenhaus, S. W., Collins, L., \& Shaw, G. (2003). Creating leadership organizations. San Francisco: BerrettKoehler Publishers Inc.

Guest, M. (2002). Comparable worth and gender discrimination: An International Perspective: Geneva: ILO.

Hiroyuki, Y., L., Kato, G., \& Ohashi, V. (2007). A new look through the glass ceiling: Where are the women? June 10 , 2019

from http://maloney.house.gov/documents/olddocs/womenscaucus/dingellmaloneyreport.pdf

Hort, J. (1981). A theory of family, economy, and gender. In R. L. Blumberg (ed.). Gender, family, and economy: The triple overlap. Newbury Park, CA: Sage Press.

Hughes, T., \& Bozionelos, L. (2007). Power play: Women, leadership and the getting of power. Ivey Business

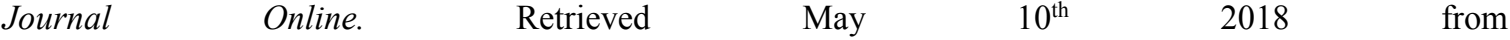
http://maloney.house.gov/documents/olddocs/womenscaucus/dingellmaloneyreport.pdf

Karimi, F. (2007). Gender-based barriers to senior management positions: Understanding the scarcity of female CEOs [Electronic version]. Journal of Business Ethics, 27, 321-334.

Keohane, N. (2007). Crossing the bridge: Reflections of women and leadership. San Francisco, CA: Jossey-Bass.

Kiruriti, H. (2010). Acknowledging the female archetype: Women managers' narratives of gender. Women in Management Review, 15(5/6), 296-303.

Merriam, S. B. (2002). Qualitative research in sociology. London: Sage publications.

Micheal, G. L. (2008). Women approach to management in schools. Nairobi. Puba Press.

Mohd, L., Noor, H., \& Amat, F. (2010). Gender differences in leadership: Current social issues and future organizational implications. The Journal of Leadership Studies, 8(4), 88-99.

Mohd, L., Noor, H., Ztanton, N., \& Young, F. (2009). Third possibility: The invisible edge that women have in complex organizations. The Learning Organization, 10(6), 77-97.

Nebolisa, E. (2009). Women and politics: Peace \& conflict monitor. Ibadan: New page publications.

Ngaaso, C. K., \& Attom, E. L. (2011). Gender issues and development in Ghana: Some policy implications. Accra: Yamens Press Ltd.

Ngimbudzi, A. (2009). The public nature of domestic violence: The discovery of domestic abuse. New York: Routledge Publications.

Rakins, B. R., Cotton, E. (1999). Gender and power in organizations: A longitudinal perspective. Psychological Bulletin, 105(1), 51-88. https://doi.org/10.1037/00332909.105.1.51

Roe, B. G. (2012). Reaching underserved populations with basic education in deprived areas of Ghana: Emerging good practices. Washington DC: World Bank.

Ruth, B. (1987). Sex segregation in the workplace. Annual Review of Sociology, 19,241-70.

Saif, S. K., Nawaz, A., \& Jan, F. A. (2012). Predicting satisfaction among the School teachers: An education management perspective (Unpublished M.Ed dissertation), University of Port Harcourt. Port Harcourt.

Shane, S. A. (2001). Cultural differences in innovation championing strategies. Journal of Management, 21, 931952.

Spencer, H. (2013). Study of sociology. Nairobi: Nebo Press.

Tanor, L. L. (2011). A guide to writing dissertations. Osu-Accra: Dieco Ventures.

The 1992 Constitution of the Republic of Ghana. Accra: Assembly Press.

Walby. R. P (2006). How women lead. New York. Sage publications.

Warring, J. (2009). Women and Leadership. London. Sage publications.

Wood, G. (2008). What does it take to get to the top: Do middle and senior managers agree? Women in Management Review, 18(3), 131-132.

Woods, F., \& Weasmer, L. (2002). An alternative approach to measuring opportunity-to-lead in high schools. Alberta Journal of Educational Research, 52(1), 107-126.

World Bank. (2008). Engendering Development: Through Gender Equality in Rights, Resources, and Voice. New York: Oxford University Press; Washington, D.C.

Youngcourt, S. (2005). The academic achievement challenge. New York: Guilford Press.

Zin, A. (2006). Managers and leaders: Are they different? Harvard Business Review, 55(3), 67-76.

Burke, P. McKeen, L. (1990). Measuring unmet need: Wives, husbands or couples. International Family Planning Perspectives, 24(4), 172-80. 